\title{
Review
}

Journal of Innate

Immunity
J Innate Immun 2017;9:243-249

DOI: $10.1159 / 000452669$
Received: September 29, 2016

Accepted after revision: October 18, 2016

Published online: December 3, 2016

\section{Role of MicroRNA in the Lung's Innate Immune Response}

\author{
Taylor S. Cohen \\ Department of Infectious Disease, Medimmune, Gaithersburg, MD, USA
}

\section{Keywords}

MicroRNA - Immune response - Respiratory host defense

\begin{abstract}
The immune response to respiratory pathogens must be robust enough to defend the host yet properly constrained such that inflammation-induced tissue damage is avoided. MicroRNA (miRNA) are small noncoding RNA which posttranscriptionally influence gene expression. In this review, we discuss recent experimental evidence of the contribution of miRNA to the lung's response to bacterial and viral pathogens.

(c) 2016 S. Karger AG, Basel
\end{abstract}

\section{Introduction}

The immune response to pathogens in the lung is tightly regulated, requiring numerous checks and balances to ensure adequate inflammatory signaling while not damaging host tissues via excessive inflammation. Cells use multiple mechanisms to regulate gene expression, including histone modification, DNA methylation, longnoncoding RNA expression and microRNA (miRNA) [1]. A key regulatory system capable of modulating most cellular pathways, miRNA are a family of small RNAs approximately 22 nucleotides in length that regulate gene

\section{KARGER}

(๑) 2016 S. Karger AG, Basel

E-Mail karger@karger.com

www.karger.com/jin expression through the inhibition of mRNA translation and mRNA degradation [2]. MiRNA regulation of the immune system has been a topic of intense investigation $[3,4]$. This review will discuss our current understanding of the contribution of miRNA to respiratory host defense against bacterial and viral pathogens. For a more in depth discussion of miRNA biology refer to the recent review articles by Valinezhad Orang et al. [5], and Ha and Kim [6].

\section{Background on miRNA}

miRNA are generally encoded in introns, and can be found in close proximity to the genes they regulate. While some miRNA share the same promotor as their target gene, this is not always the case. Therefore, identification of the miRNA target has been driven mostly by sequencebased prediction. Known miRNA and their target genes have been tabulated in the miRNA database miRBase [7, 8]. miRNA are transcribed from the genome by RNA Pol II, and possibly by viral Pol III, resulting in the production of primary miRNA, which are approximately $1 \mathrm{~kb}$ in size [9]. The nuclear RNase III Drosha then cleaves the stem-loop structure forming a hairpin-shaped (approximately 65 nucleotide) pre-miRNA [10]. The pre-miRNA then forms a complex with exportin 5 and GTP-binding nuclear protein RAN-GTP, which shuttles the pre- 
miRNA into the cytoplasm where the GTP is hydrolyzed and the pre-miRNA is released. The final step in miRNA formation occurs here in the cytoplasm where it is cleaved by Dicer and incorporated into the RNA-induced silencing complex, where it interacts with its target RNA.

Host cells activate miRNA transcription following the recognition of pathogen-associated molecular patterns (PAMPs) by receptors such as the Toll-like family [11-14]. Downstream of PAMP receptors, signaling pathways, including molecules such as NF- $\mathrm{BB}$ (nuclear factor kappa-light-chain-enhancer of activated B cells), mitogen-activated protein kinases, signaling transducer and activator of transcription, regulate the transcription of miRNA along with their target genes [15-19]. The miRNA then act to limit the production of the target gene, acting as an internal break on gene transcription. This review focuses on recent findings on the contribution of miRNA to the response of host cells to respiratory pathogens.

\section{miRNA in Specific Cell Populations}

\section{Epithelium}

The airway epithelium, while not traditionally considered a component of the immune system, is uniquely positioned to significantly contribute to host defense against respiratory pathogens. The primary function of the epithelium is as a barrier separating "dirty" air from the "clean" blood stream. However, the epithelium is more than just a barrier. The epithelium is located such that it is constantly exposed to potential pathogens, and therefore has a critical role in initiating and coordinating host defense responses [20]. Its role in host defense is highlighted clinically by the increased infection rates of smokers and individuals with chronic obstructive pulmonary disease (COPD) and cystic fibrosis (CF), each associated with altered epithelial cell function [20-23].

miRNA are involved in all aspects of epithelial regulation. In order to maintain the physical barrier separating out from in, the epithelium is required to rapidly replace any dying or dead cells such that pathogens cannot cross the breach created by cell loss. During wound healing or mechanical stretch, the expression of a large number of miRNA is altered, suggesting a coordinated response to the physical stress through miRNA regulation [24, 25]. Epithelial renewal following injury is dependent on the transcription factor c-Myc, which in turn regulates a family of approximately 17 unique miRNA, including miR126, miR-34c, miR-130a, miR-574, miR-193b, miR-19b,
miR-125b, miR-17, miR-214, and miR-34b [26]. These miRNA were predicted to target essential components of cellular proliferation, including polo-like kinase 4, tenascin $C$, and ubiquitin specific peptidase 1 .

Epithelial wounding/healing is associated with the activation of signaling pathways, such as p38 MAP kinase and myosin light chain kinase, which promotes actin polymerization and epithelial regeneration [27-30]. Activation of this p38 in epithelial cells suppresses miR-17-92, therefore suppressing a negative regulator of lung development [31]. Two other key miRNA, miR-155 and miR23a, are downregulated in epithelial cells infected with Klebsiella pneumoniae. These 2 miRNA act through high mobility group nucleosomal-binding domain 2 and nuclear factor 1 to regulate $\alpha 5 \beta 1$ integrin expression and actin polymerization at the cell surface, and to restrict K. pneumoniae adhesion [32].

The epithelium is also able to respond to pathogens by producing cytokines responsible for recruiting professional phagocytes such as neutrophils and by producing antimicrobial peptides to directly kill pathogens. miRNA are involved in both pathogen survival and innate immune function. The respiratory syncytial virus downregulates miR-221 in epithelial cells, reducing epithelial apoptosis and increasing viral replication, while influenza A downregulates miR-17-3p as well as miR221 , which also promotes viral replication $[33,34]$. The downregulation of miR-276 during viral influenza A infection promotes epithelial apoptosis and viral clearance; therefore, a balance must exist to properly regulate the influence of miRNA on epithelial apoptosis. Pathogen killing is influenced by miRNA. For example, during influenza A infection, upregulation of miR-136 promotes IFN- $\beta$ accumulation in an A549 epithelial cell model, promoting viral killing [35]. In response to bacteria such as Mycobacterium bovis, Staphylococcus aureus, or Pseudomonas aeruginosa altered expression of miR-21, miR-124, and miR-93 regulates production of inflammatory cytokines, such as IL- 8 , by the epithelium [36-38].

\section{Macrophages}

Respiratory macrophages, both resident alveolar macrophages and recruited inflammatory monocytes, have essential roles in the host defense against respiratory pathogens. Depletion of resident macrophages impairs host defense against a range of bacterial pathogens, including $S$. aureus, K. pneumoniae, and some $P$. aeruginosa isolates, as well as viral pathogens, respiratory syncytial virus and influenza A [39-43]. These cells are also 
Fig. 1. Immune functions influenced by miRNA in the lung. NET, neutrophil extracellular trap; TLR, Toll-like receptor.

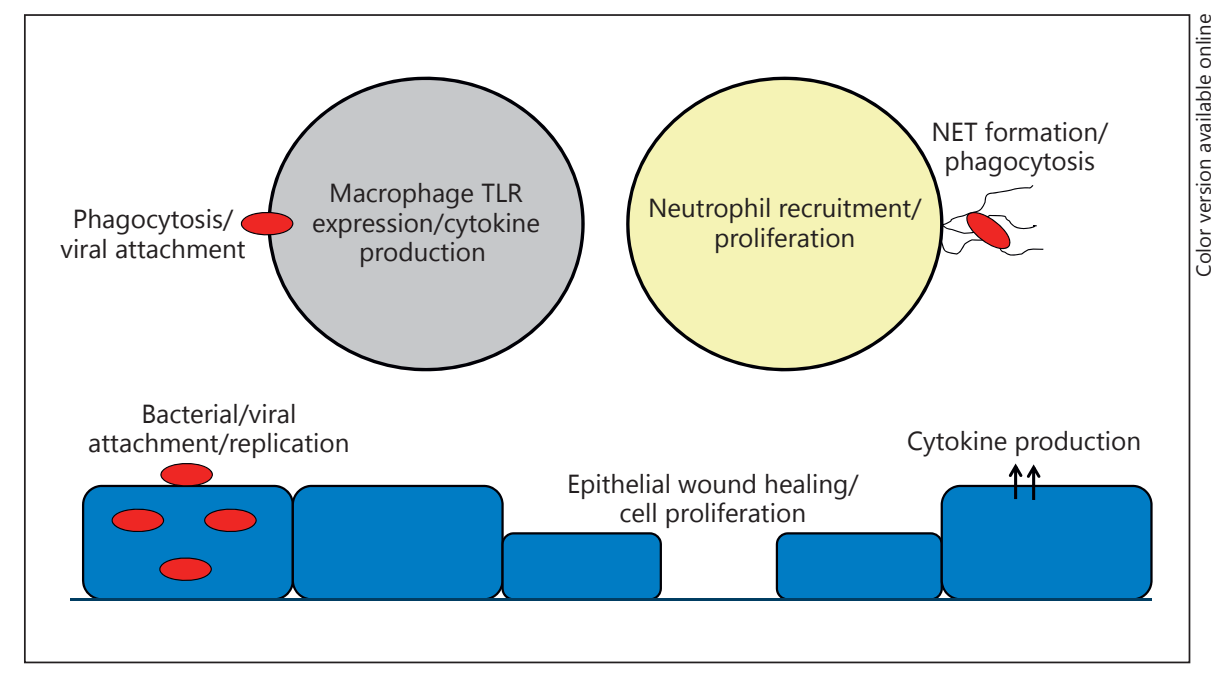

capable of promoting tissue damage during infections by pathogens such as ExoS+ P. aeruginosa and metapneumovirus $[44,45]$.

Macrophage binding to pathogens facilitates not only uptake and killing, but also antigen processing for the development of memory immune responses. Conversely, the attachment of viruses to the cell surface enables invasion of the cytoplasm and viral replication. Therefore, it is important that host cells are capable of tuning the expression of surface proteins involved in these processes such that phagocytic killing is enabled while viral replication is prevented. MiR-155 directly influences the phagocytosis of bacterial pathogens such as $P$. aeruginosa and $S$. aureus by modifying expression of the scavenger receptor MARCO [46]. Another scavenger receptor, CD163, enables the invasion and replication of PRRSV (porcine reproductive and respiratory syndrome virus) [47]. Alveolar macrophages suppress CD163 by upregulating miR-181 in response to this virus, thereby limiting viral replication [48]. Once the virus is internalized, miR-125b targets the NF- $\kappa B$ to further limit PRRSV replication [49]. Therefore, by limiting surface binding and targeting signaling activated in response to internalized viruses, miRNA act to prevent the propagation of viral infection by limiting viral replication.

miRNA have been implicated in the regulation of multiple macrophage responses to respiratory pathogens. Toll-like receptors (TLR) are major receptors for pathogens, and they are directly influenced by miRNA [50]. MiR-124 targets TNF receptor-associated factor 6 (TRAF6), which is necessary for signaling downstream of TLRs [38]. Other miRNA alter the expression of signaling regulators, such as dual specificity protein phosphatase 1 (DUSP1), targeted by miR-429, interleukin-1 receptorassociated kinase 4(IRAK4), targeted by miR-302b, and phosphatase and tensin homolog (PTEN), targeted by miR-26b [14, 51, 52]. Macrophages also activate antimicrobial signaling pathways in nearby immune cells. One such pathway is the IL-23/IL-17 pathway shown to contribute to the host response to numerous pathogens [53, 54]. Multiple miRNA target this pathway, including miR146 and miR-155 [55-57]. These miRNA are therefore able to regulate the alveolar macrophage's response to multiple pathogens by influencing proteins central to multiple signaling pathways.

\section{Neutrophils}

Neutrophils are the most abundant of the immune cells, estimated to comprise up to $80 \%$ of the total immune cell population, although in an uninfected host most of these cells reside in lymphoid tissue, such as the bone marrow and spleen, or are adherent to the vascular endothelium (marginating pool). Primarily studied in the context of bacterial and fungal infection, neutrophils are essential for proper defense against most pathogens [39, $58,59]$. Clinical diseases such as chronic granulomas disease are associated with defects in neutrophil function, and as such these patients are highly susceptible to infection, especially with bacterial (S. aureus, Klebsiella species, $P$. aeruginosa) and fungal (Aspergillus and Candida species) pathogens [60]. While the role of neutrophils is less studied in the context of respiratory viral infection, it is clear that neutrophils also play a protective role in a variety of viral pneumonias [61-63]. 
Table 1. Contribution of miRNA to cellular immune responses

\begin{tabular}{|c|c|c|c|}
\hline Cell & miRNA & Function & Reference \\
\hline \multirow[t]{9}{*}{ Epithelium } & $\begin{array}{l}\text { miR-17 } \\
\text { miR-19b } \\
\text { miR-34b } \\
\text { miR-34c } \\
\text { miR-125b } \\
\text { miR-126 } \\
\text { miR-130a } \\
\text { miR-193b } \\
\text { miR-214 } \\
\text { miR-574 }\end{array}$ & Proliferation & 26 \\
\hline & miR-17-92 & $\begin{array}{l}\text { Actin polymerization/ } \\
\text { lung development }\end{array}$ & 31 \\
\hline & miR-23a & $\begin{array}{l}\text { Actin polymerization/ } \\
\text { integrin expression }\end{array}$ & 32 \\
\hline & $\operatorname{miR}-155$ & & \\
\hline & miR-221 & Apoptosis & 33 \\
\hline & $\operatorname{miR}-17-3 p$ & $\begin{array}{l}\text { Apoptosis/ } \\
\text { viral replication }\end{array}$ & 34 \\
\hline & $\operatorname{miR}-221$ & & \\
\hline & $\operatorname{miR}-276$ & & \\
\hline & miR-136 & IFN- $\beta$ & 35 \\
\hline \multirow[t]{9}{*}{ Macrophage } & miR-155 & Phagocytosis & 46 \\
\hline & mIR-181 & Viral internalization & 48 \\
\hline & miR-125b & Viral replication & 49 \\
\hline & miR-124 & TRAF6/TLR signaling & 38 \\
\hline & $\operatorname{miR}-429$ & DUSP1 & 14 \\
\hline & miR-302b & IRAK4 & 51 \\
\hline & miR-26b & PTEN & 52 \\
\hline & miR-146 & IL-23/IL-17 & $55-57$ \\
\hline & miR-155 & & \\
\hline \multirow[t]{4}{*}{ Neutrophil } & $\begin{array}{l}\operatorname{miR} 155 \\
\operatorname{miR}-223\end{array}$ & Chemokine production & 64 \\
\hline & miR-223 & Granulocyte proliferation & 65 \\
\hline & $\mathrm{miR}-146 \mathrm{a}$ & $\begin{array}{l}\text { Antimicrobial processes/ } \\
\text { phagocytosis, reactive }\end{array}$ & 66,67 \\
\hline & miR-328 & oxygen species & \\
\hline
\end{tabular}

Regulation of neutrophil function is required to prevent neutrophil-mediated host damage. As part of their antimicrobial arsenal, neutrophils release multiple proinflammatory mediators including cytokines, proteases, and DNA. If left unregulated overwhelming inflammation can result in tissue damage. miRNA play a central role in neutrophil regulation. Neutrophil recruitment is influenced by miR-155 and miR-223, which reduce chemokine production in response to pathogens [64]. miR223 is also able to prevent granulocyte proliferation, limiting the numbers of neutrophils available to respond to infection [65]. Antimicrobial function is directly influenced by miRNA. miR-146a and miR-328 negatively regulate neutrophil elastase, phagocytosis, and reactive oxygen species production, limiting the killing capacity of the neutrophil $[66,67]$. Neutrophil extracellular traps, or extruded DNA used by neutrophils to trap and kill pathogens, are in part driven by IFN- $\gamma$. This process is regulated by miRNA, although the specific miRNA have yet to be determined [68]. Loss of miRNA regulation of neutrophil function therefore has the capacity to severely impair host defense in the lung.

\section{T Cells}

$\mathrm{T}$ cells and natural killer $\mathrm{T}$ cells have been shown to both protect against respiratory infection as well as contribute to inflammatory tissue damage during such infections. These cells contribute to both the innate response and adaptive immune response to respiratory pathogens, and therefore it is highly likely that miRNA contribute to the regulation of these cell populations. Currently, there is a paucity of data directly testing this hypothesis; however, a handful of studies have looked at miRNA regulation of these cells in the context of other respiratory diseases which are commonly associated with infection. The IL-22/IL-17 signaling axis can promote viral clearance when properly regulated, but high expression levels, or activation of this pathway, can result in inflammatory tissue damage [69, 70]. Cellular regulators such as miRNA are therefore uniquely positioned to regulate this pathway, and in fact miR-323-3p, miR-19, and miR-22 have been shown to alter the IL-17 pathway in the lungs of smokers and subjects who suffer allergic reactions and asthma [71-73]. Therefore, while not directly tested, there is evidence to suggest that miRNA regulate natural killer and $\mathrm{T}$ cell function during respiratory infection.

\section{miRNA in Inflammatory Respiratory Disease}

Pulmonary diseases such as COPD and CF are associated with pathogen-induced exacerbations or chronic infection $[12,21,74]$. There is mounting evidence that miRNA expression is altered in these diseases, potentially impairing immunity against pathogens in the lung; however, few studies have been published describing the role of individual miRNA in these diseases [75-77]. Microarray analysis of COPD lung samples identified miRNA218-5p as being downregulated in the airway epithelium [78]. Using a smoke-induced COPD murine model, Conickx et al. [78] showed that a miR-218-5p mimic protected against smoke-induced inflammation, confirming 
its role in COPD-associated inflammation. In macrophages, the autophagy process has a central role in the response to phagocytosed pathogens, and miRNA have been identified as key regulators of autophagy [79-82]. Recent work has identified a cluster of miRNA, miR1792, that is elevated in CF macrophages [83]. These miRNA negatively regulate the autophagy pathway and CFTR expression, impairing host response to CF-related pathogens such as Burkholderia cenocepacia. Altered miR-31 in CF epithelial cells also contributes to the chronic inflammation associated with this disease [37]. Reduced levels of miR-31 results in the uncontrolled production of cathepsin $S$, which degrades essential antimicrobial peptides such as lactoferrin and $\beta$-defensins. Loss of these antimicrobial peptides makes the lung more susceptible to colonization with pathogens such as $P$. aeruginosa. Targeting miRNA in a therapeutic setting presents an exciting opportunity to correct some of the immune defects associated with these respiratory diseases [84].

\section{Conclusions}

miRNA act as key regulators of multiple cellular processes; however, testing their contribution to pulmonary immunity has only recently begun. Multiple cell types contribute to host defense in the lung, and miRNA regulate processes in each, including epithelial cells, macrophages, neutrophils and T cells, among others (Table 1; Fig. 1). Our understanding of how individual miRNA are regulated and which genes they target is still being developed, which has hampered the targeting of miRNA in the clinic. The next phase of miRNA development for clinical application involves not only more detailed analysis of miRNA biology, but also the invention of a methodology to target miRNA modulators to specific cell types. The ability to tailor miRNA therapy such that their capacity can be harnessed in a cell-specific and regulated manner has the potential to benefit patients suffering from a myriad of respiratory infections.

\section{References}

1 Netea MG, Joosten LA, Latz E, Mills KH, Natoli G, Stunnenberg HG, O’Neill LA, Xavier RJ: Trained immunity: a program of innate immune memory in health and disease. Science 2016;352:aaf1098.

2 Hausser J, Zavolan M: Identification and consequences of miRNA-target interactions - beyond repression of gene expression. Nat Rev Genet 2014;15:599-612.

3 Devasthanam AS, Tomasi TB: Dicer in immune cell development and function. Immunol Invest 2014;43:182-195.

4 Maudet C, Mano M, Eulalio A: MicroRNAs in the interaction between host and bacterial pathogens. FEBS Lett 2014;588:4140-4147.

5 Valinezhad Orang A, Safaralizadeh R, Kazemzadeh-Bavili M: Mechanisms of miRNAmediated gene regulation from common downregulation to mRNA-specific upregulation. Int J Genomics 2014;2014:970607.

$6 \mathrm{Ha} \mathrm{M}$, Kim VN: Regulation of microRNA biogenesis. Nat Rev Mol Cell Biol 2014;15: 509-524.

7 Kozomara A, Griffiths-Jones S: miRBase: annotating high confidence microRNAs using deep sequencing data. Nucleic Acids Res 2014;42:D68-D73.

8 Kozomara A, Griffiths-Jones S: miRBase: integrating microRNA annotation and deepsequencing data. Nucleic Acids Res 2011; 39:D152-D157.

9 Lee Y, Kim M, Han J, Yeom KH, Lee S, Baek $\mathrm{SH}$, Kim VN: MicroRNA genes are transcribed by RNA polymerase II. EMBO J 2004; 23:4051-4060.
10 Lee Y, Ahn C, Han J, Choi H, Kim J, Yim J, Lee J, Provost P, Radmark O, Kim S, Kim VN: The nuclear RNase III Drosha initiates microRNA processing. Nature 2003;425:415419.

11 Naqvi AR, Zhong S, Dang H, Fordham JB, Nares S, Khan A: Expression profiling of LPS responsive miRNA in primary human macrophages. J Microb Biochem Technol 2016;8: 136-143.

12 Vencken SF, Greene CM: Toll-like receptors in cystic fibrosis: impact of dysfunctional microRNA on innate immune responses in the cystic fibrosis lung. J Innate Immun 2016; 8:541-549.

13 Hasler R, Jacobs G, Till A, Grabe N, Cordes C, Nikolaus S, Lao K, Schreiber S, Rosenstiel P: Microbial pattern recognition causes distinct functional micro-RNA signatures in primary human monocytes. PLoS One 2012;7:e31151.

14 Xiao J, Tang J, Chen Q, Tang D, Liu M, Luo M, Wang Y, Wang J, Zhao Z, Tang C, Wang D, Mo Z: miR-429 regulates alveolar macrophage inflammatory cytokine production and is involved in LPS-induced acute lung injury. Biochem J 2015;471:281-291.

15 Jiang X: Different signal pathways regulate IL$1 \beta$-induced mature and primary miRNA146a expression in human alveolar epithelial cells. Acta Physiol Hung 2014;101:282-290.

16 Shen J, Hung MC: Signaling-mediated regulation of MicroRNA processing. Cancer Res 2015;75:783-791.
17 Cohen TS, Prince AS: Bacterial pathogens activate a common inflammatory pathway through IFN $\lambda$ regulation of PDCD4. PLoS Pathog 2013;9:e1003682.

18 Li Y, Li J, Belisle S, Baskin CR, Tumpey TM, Katze MG: Differential microRNA expression and virulence of avian, 1918 reassortant, and reconstructed 1918 influenza A viruses. Virology 2011;421:105-113.

19 Li Y, Chan EY, Li J, Ni C, Peng X, Rosenzweig E, Tumpey TM, Katze MG: MicroRNA expression and virulence in pandemic influenza virus-infected mice. J Virol 2010;84:30233032.

20 Parker D, Prince A: Innate immunity in the respiratory epithelium. Am J Respir Cell Mol Biol 2011;45:189-201.

21 Cohen TS, Prince A: Cystic fibrosis: a mucosal immunodeficiency syndrome. Nat Med 2012; 18:509-519.

22 Davies DE: Epithelial barrier function and immunity in asthma. Ann Am Thorac Soc 2014;11(suppl 5):S244-S251.

23 Hiemstra PS, McCray PB,Jr, Bals R: The innate immune function of airway epithelial cells in inflammatory lung disease. Eur Respir J 2015;45:1150-1162.

24 Szczepankiewicz A, Lackie PM, Holloway JW: Altered microRNA expression profile during epithelial wound repair in bronchial epithelial cells. BMC Pulm Med 2013;13:63.

25 Yehya N, Yerrapureddy A, Tobias J, Margulies SS: MicroRNA modulate alveolar epithelial response to cyclic stretch. BMC Genomics 2012;13:154. 
26 Dong J, Sutor S, Jiang G, Cao Y, Asmann YW, Wigle DA: c-Myc regulates self-renewal in bronchoalveolar stem cells. PLoS One 2011; 6:e23707.

27 Cohen TS, DiPaolo BC, Lawrence GG, Margulies SS: Sepsis enhances epithelial permeability with stretch in an actin dependent manner. PLoS One 2012;7:e38748.

28 Cohen TS, Gray Lawrence G, Khasgiwala A, Margulies SS: MAPK activation modulates permeability of isolated rat alveolar epithelial cell monolayers following cyclic stretch. PLoS One 2010;5:e10385.

29 DiPaolo BC, Margulies SS: Rho kinase signaling pathways during stretch in primary alveolar epithelia. Am J Physiol Lung Cell Mol Physiol 2012;302:L992-L1002.

30 DiPaolo BC, Lenormand G, Fredberg JJ, Margulies SS: Stretch magnitude and frequencydependent actin cytoskeleton remodeling in alveolar epithelia. Am J Physiol Cell Physiol 2010;299:C345-C353.

31 Oeztuerk-Winder F, Guinot A, Ochalek A, Ventura JJ: Regulation of human lung alveolar multipotent cells by a novel p38a MAPK/ miR-17-92 axis. EMBO J 2012;31:3431-3441.

32 Teng Y, Miao J, Shen X, Yang X, Wang X, Ren L, Wang X, Chen J, Li J, Chen S, Wang Y, Huang N: The modulation of MiR-155 and MiR-23a manipulates Klebsiella pneumoniae adhesion on human pulmonary epithelial cells via integrin $\alpha 5 \beta 1$ signaling. Sci Rep 2016; 6:31918.

33 Othumpangat S, Walton C, Piedimonte G: MicroRNA-221 modulates RSV replication in human bronchial epithelium by targeting NGF expression. PLoS One 2012;7:e30030.

34 Nakamura S, Horie M, Daidoji T, Honda T, Yasugi M, Kuno A, Komori T, Okuzaki D, Narimatsu H, Nakaya T, Tomonaga K: Influenza A virus-induced expression of a GalNAc transferase, GALNT3, via MicroRNAs is required for enhanced viral replication. J Virol 2015;90:1788-1801.

35 Zhao L, Zhu J, Zhou H, Zhao Z, Zou Z, Liu X, Lin X, Zhang X, Deng X, Wang R, Chen H, Jin M: Identification of cellular microRNA-136 as a dual regulator of RIG-I-mediated innate immunity that antagonizes H5N1 IAV replication in A549 cells. Sci Rep 2015;5:14991.

36 Sheedy FJ, Palsson-McDermott E, Hennessy EJ, Martin C, O'Leary JJ, Ruan Q, Johnson DS, Chen Y, O'Neill LA: Negative regulation of TLR4 via targeting of the proinflammatory tumor suppressor PDCD4 by the microRNA miR-21. Nat Immunol 2010;11:141-147.

37 Weldon S, McNally P, McAuley DF, Oglesby IK, Wohlford-Lenane CL, Bartlett JA, Scott CJ, McElvaney NG, Greene CM, McCray PB Jr, Taggart CC: miR-31 dysregulation in cystic fibrosis airways contributes to increased pulmonary cathepsin S production. Am J Respir Crit Care Med 2014;190:165-174.
38 Ma C, Li Y, Li M, Deng G, Wu X, Zeng J, Hao X, Wang X, Liu J, Cho WC, Liu X, Wang Y: microRNA-124 negatively regulates TLR signaling in alveolar macrophages in response to mycobacterial infection. Mol Immunol 2014; 62:150-158.

39 Cohen TS, Hilliard JJ, Jones-Nelson O, Keller AE, O’Day T, Tkaczyk C, DiGiandomenico A, Hamilton M, Pelletier M, Wang Q, Diep BA, Le VT, Cheng L, Suzich J, Stover CK, Sellman BR: Staphylococcus aureus a toxin potentiates opportunistic bacterial lung infections. Sci Transl Med 2016;8:329ra31.

40 Martin FJ, Parker D, Harfenist BS, Soong G, Prince A: Participation of CD11 $\mathrm{c}^{+}$leukocytes in methicillin-resistant Staphylococcus aureus clearance from the lung. Infect Immun 2011; 79:1898-1904.

41 Kim HM, Lee YW, Lee KJ, Kim HS, Cho SW, van Rooijen N, Guan Y, Seo SH: Alveolar macrophages are indispensable for controlling influenza viruses in lungs of pigs. J Virol 2008;82:4265-4274.

42 Kim HM, Kang YM, Ku KB, Park EH, Yum J, Kim JC, Jin SY, Lee JS, Kim HS, Seo SH: The severe pathogenicity of alveolar macrophagedepleted ferrets infected with 2009 pandemic H1N1 influenza virus. Virology 2013;444: 394-403.

43 Schneider C, Nobs SP, Heer AK, Kurrer M, Klinke G, van Rooijen N, Vogel J, Kopf M: Alveolar macrophages are essential for protection from respiratory failure and associated morbidity following influenza virus infection. PLoS Pathog 2014;10:e1004053.

44 Kolli D, Gupta MR, Sbrana E, Velayutham TS Chao H, Casola A, Garofalo RP: Alveolar macrophages contribute to the pathogenesis of human metapneumovirus infection while protecting against respiratory syncytial virus infection. Am J Respir Cell Mol Biol 2014;51: 502-515.

45 Cohen TS, Prince AS: Activation of inflammasome signaling mediates pathology of acute $P$. aeruginosa pneumonia. J Clin Invest 2013;123:1630-1637.

46 Domingo-Gonzalez R, Katz S, Serezani CH, Moore TA, Levine AM, Moore BB: Prostaglandin E2-induced changes in alveolar macrophage scavenger receptor profiles differentially alter phagocytosis of Pseudomonas aeruginosa and Staphylococcus aureus post-bone marrow transplant. J Immunol 2013;190: 5809-5817.

47 Calvert JG, Slade DE, Shields SL, Jolie R, Mannan RM, Ankenbauer RG, Welch SK: CD163 expression confers susceptibility to porcine reproductive and respiratory syndrome viruses. J Virol 2007;81:7371-7379.

48 Gao L, Guo XK, Wang L, Zhang Q, Li N, Chen XX, Wang Y, Feng WH: MicroRNA 181 suppresses porcine reproductive and respiratory syndrome virus (PRRSV) infection by targeting PRRSV receptor CD163. J Virol 2013;87: 8808-8812.
49 Wang D, Cao L, Xu Z, Fang L, Zhong Y, Chen Q, Luo R, Chen H, Li K, Xiao S: MiR-125b reduces porcine reproductive and respiratory syndrome virus replication by negatively regulating the NF- $\kappa B$ pathway. PLoS One 2013 8:e55838.

50 Xu G, Zhang Z, Xing Y, Wei J, Ge Z, Liu X, Zhang Y, Huang X: MicroRNA-149 negatively regulates TLR-triggered inflammatory response in macrophages by targeting MyD88. J Cell Biochem 2014;115:919-927.

51 Zhang L, Huang C, Guo Y, Gou X, Hinsdale M, Lloyd P, Liu L: MicroRNA-26b modulates the NF- $\kappa B$ pathway in alveolar macrophages by regulating PTEN. J Immunol 2015;195: 5404-5414.

52 Zhou X, Li X, Ye Y, Zhao K, Zhuang Y, Li Y, Wei Y, Wu M: MicroRNA-302b augments host defense to bacteria by regulating inflammatory responses via feedback to TLR/IRAK4 circuits. Nat Commun 2014;5:3619.

53 McAleer JP, Kolls JK: Directing traffic: IL-17 and IL-22 coordinate pulmonary immune defense. Immunol Rev 2014;260:129-144.

54 O'Quinn DB, Palmer MT, Lee YK, Weaver CT: Emergence of the Th17 pathway and its role in host defense. Adv Immunol 2008;99: $115-163$.

55 Podsiad A, Standiford TJ, Ballinger MN, Eakin R, Park P, Kunkel SL, Moore BB, Bhan U: MicroRNA-155 regulates host immune response to postviral bacterial pneumonia via IL-23/IL-17 pathway. Am J Physiol Lung Cell Mol Physiol 2016;310:L465-L475.

56 Hoces de la Guardia A, Staedel C, Kaafarany I, Clement A, Roubaud Baudron C, Megraud F, Lehours P: Inflammatory cytokine and microRNA responses of primary human dendritic cells cultured with Helicobacter pylori strains. Front Microbiol 2013;4:236.

57 Griss K, Bertrams W, Sittka-Stark A, Seidel K, Stielow C, Hippenstiel S, Suttorp N, Eberhardt M, Wilhelm J, Vera J, Schmeck B: MicroRNAs constitute a negative feedback loop in Streptococcus pneumoniae-induced macrophage activation. J Infect Dis 2016;214:288299.

58 Xiong H, Carter RA, Leiner IM, Tang YW, Chen L, Kreiswirth BN, Pamer EG: Distinct contributions of neutrophils and CCR2+ monocytes to pulmonary clearance of different Klebsiella pneumoniae strains. Infect Immun 2015;83:3418-3427.

59 Dejima T, Shibata K, Yamada H, Hara H, Iwakura Y, Naito S, Yoshikai Y: Protective role of naturally occurring interleukin-17Aproducing $\gamma \delta$ T cells in the lung at the early stage of systemic candidiasis in mice. Infect Immun 2011;79:4503-4510.

60 Leiding JW, Holland SM: Chronic granulomatous disease; in Pagon RA, Adam MP, Ardinger $\mathrm{HH}$, Wallace SE, Amemiya A, Bean LJH, Bird TD, Fong CT, Mefford HC, Smith RJH, Stephens K (eds): GeneReviews. Seattle, University of Washington, 1993. 
61 Bradley LM, Douglass MF, Chatterjee D, Akira S, Baaten BJ: Matrix metalloprotease 9 mediates neutrophil migration into the airways in response to influenza virus-induced tolllike receptor signaling. PLoS Pathog 2012;8: e1002641.

62 Tate MD, Deng YM, Jones JE, Anderson GP, Brooks AG, Reading PC: Neutrophils ameliorate lung injury and the development of severe disease during influenza infection. J Immunol 2009; 183:7441-7450.

63 Stokes KL, Currier MG, Sakamoto K, Lee S, Collins PL, Plemper RK, Moore ML: The respiratory syncytial virus fusion protein and neutrophils mediate the airway mucin response to pathogenic respiratory syncytial virus infection. J Virol 2013;87:10070-10082.

64 Dorhoi A, Iannaccone M, Farinacci M, Fae KC, Schreiber J, Moura-Alves P, Nouailles G, Mollenkopf HJ, Oberbeck-Muller D, Jorg S, Heinemann E, Hahnke K, Lowe D, Del Nonno F, Goletti D, Capparelli R, Kaufmann SH: MicroRNA-223 controls susceptibility to tuberculosis by regulating lung neutrophil recruitment. J Clin Invest 2013;123:4836-4848.

65 Johnnidis JB, Harris MH, Wheeler RT, Stehling-Sun S, Lam MH, Kirak O, Brummelkamp TR, Fleming MD, Camargo FD: Regulation of progenitor cell proliferation and granulocyte function by microRNA-223. Nature 2008; 451:1125-1129.

66 Tay HL, Kaiko GE, Plank M, Li J, Maltby S, Essilfie AT, Jarnicki A, Yang M, Mattes J, Hansbro PM, Foster PS: Antagonism of miR328 increases the antimicrobial function of macrophages and neutrophils and rapid clearance of non-typeable Haemophilus influenzae (NTHi) from infected lung. PLoS Pathog 2015;11:e1004549.

67 Zhong T, Perelman JM, Kolosov VP, Zhou XD: MiR-146a negatively regulates neutrophil elastase-induced MUC5AC secretion from 16HBE human bronchial epithelial cells. Mol Cell Biochem 2011;358:249-255.
68 Yamada M, Gomez JC, Chugh PE, Lowell CA, Dinauer MC, Dittmer DP, Doerschuk CM: Interferon-gamma production by neutrophils during bacterial pneumonia in mice. Am J Respir Crit Care Med 2011;183:13911401.

69 Bystrom J, Al-Adhoubi N, Al-Bogami M, Jawad AS, Mageed RA: Th17 lymphocytes in respiratory syncytial virus infection. Viruses 2013;5:777-791.

70 Dubin PJ, McAllister F, Kolls JK: Is cystic fibrosis a TH17 disease? Inflamm Res 2007;56: 221-227.

71 Karner J, Wawrzyniak M, Tankov S, Runnel T, Aints A, Kisand K, Altraja A, Kingo K, Akdis CA, Akdis M, Rebane A: Increased microRNA-323-3p in IL-22/IL-17-producing T cells and asthma: a role in the regulation of the TGF- $\beta$ pathway and IL- 22 production. Allergy 2016, Epub ahead of print.

72 Lu W, You R, Yuan X, Yang T, Samuel EL, Marcano DC, Sikkema WK, Tour JM, Rodriguez A, Kheradmand F, Corry DB: The microRNA miR-22 inhibits the histone deacetylase HDAC4 to promote $\mathrm{T}_{\mathrm{H}} 17$ cell-dependent emphysema. Nat Immunol 2015;16: 1185-1194.

73 Simpson LJ, Patel S, Bhakta NR, Choy DF, Brightbill HD, Ren X, Wang Y, Pua HH, Baumjohann D, Montoya MM, Panduro M, Remedios KA, Huang X, Fahy JV, Arron JR, Woodruff PG, Ansel KM: A microRNA upregulated in asthma airway $\mathrm{T}$ cells promotes TH2 cytokine production. Nat Immunol 2014;15:1162-1170.

74 Sethi S: Bacteria in exacerbations of chronic obstructive pulmonary disease: phenomenon or epiphenomenon? Proc Am Thorac Soc 2004;1:109-114.
75 Kara M, Kirkil G, Kalemci S: Differential expression of microRNAs in chronic obstructive pulmonary disease. Adv Clin Exp Med 2016;25:21-26

76 McKiernan PJ, Greene CM: MicroRNA dysregulation in cystic fibrosis. Mediators Inflamm 2015;2015:529642.

$77 \mathrm{Xu} \mathrm{W}$, Hui C, Yu SS, Jing C, Chan HC: MicroRNAs and cystic fibrosis - an epigenetic perspective. Cell Biol Int 2011;35:463-466.

78 Conickx G, Mestdagh P, Avila Cobos F, Verhamme FM, Maes T, Vanaudenaerde BM, Seys LJ, Lahousse L, Kim RY, Hsu AC, Wark PA, Hansbro PM, Joos GF, Vandesompele J, Bracke KR, Brusselle GG: MicroRNA profiling reveals a role for microRNA-218-5p in the pathogenesis of chronic obstructive pulmonary disease. Am J Respir Crit Care Med 2016, Epub ahead of print.

79 Saitoh T, Akira S: Regulation of inflammasomes by autophagy. J Allergy Clin Immunol 2016;138:28-36.

80 Weiss G, Schaible UE: Macrophage defense mechanisms against intracellular bacteria. Immunol Rev 2015;264:182-203.

81 Schmid D, Dengjel J, Schoor O, Stevanovic S, Munz C: Autophagy in innate and adaptive immunity against intracellular pathogens. J Mol Med (Berl) 2006;84:194-202.

82 Zhai H, Fesler A, Ju J: MicroRNA: a third dimension in autophagy. Cell Cycle 2013;12: 246-250.

83 Tazi MF, Dakhlallah DA, Caution K, Gerber MM, Chang SW, Khalil H, Kopp B, Ahmed A, Krause K, Davis I, Marsh C, Lovett-Racke AE, Schlesinger LS, Cormet-Boyaka E, Amer AO: Elevated Mirc1/Mir17-92 cluster expression negatively regulates autophagy and CFTR (cystic fibrosis transmembrane conductance regulator) function in $\mathrm{CF}$ macrophages. Autophagy 2016;12:2026-2037.

84 Maltby S, Plank M, Tay HL, Collison A, Foster PS: Targeting MicroRNA function in respiratory diseases: mini-review. Front Physiol 2016;7:21. 